\title{
Moss bag (Sphagnum papillosum) magnetic and elemental properties for characterising seasonal and spatial variation in urban pollution
}

\author{
H. Salo ${ }^{1} \cdot$ P. Paturi ${ }^{2} \cdot$ J. Mäkinen ${ }^{1}$
}

Received: 15 October 2015/Revised: 9 March 2016/Accepted: 12 April 2016/Published online: 25 April 2016

(C) Islamic Azad University (IAU) 2016

\begin{abstract}
This study investigates the seasonal and spatial variation of traffic-induced particle matter in order to evaluate the pollutant distribution and the representativeness of the single air quality monitoring station in the city centre of Turku, southwest Finland. Study focused on parks, kindergarten and school yards as well as heavily trafficked sites. Sampling was done using active magnetic biomonitoring, which is highly applicable in polluted areas lacking native species. Sphagnum papillosum moss bags were exposed separately in road dust period, which is experienced after snow melt and the resuspension of sanding material in spring, and summer season for about 60 days in 2013. Moss bags are magnetically and elementally (e.g. Al, $\mathrm{Cr}, \mathrm{Fe}, \mathrm{Na}, \mathrm{Ni}, \mathrm{Pb}$ ) more enriched in road dust period and near heavily trafficked sites than in summer season and in the courtyard or park sites. Magnetic properties indicate that particle matter is composed of finegrained pseudo-single-domain magnetite towards superparamagnetic-single-domain grain sizes. Intensive road dust period overrides the variation of prevailing conditions as indicated by three paired samples showing finer grain sizes and higher element levels in courtyard/park sites than in traffic sites in summer. The results emphasise the effectiveness of active magnetic biomonitoring for the assessment of spatially representative air quality monitoring stations and related modelling approaches.
\end{abstract}

H. Salo

hanna.salo@utu.fi

1 Department of Geography and Geology, University of Turku, 20014 Turku, Finland

2 Wihuri Physical Laboratory, Department of Physics and Astronomy, University of Turku, 20014 Turku, Finland
Keywords Active biomonitoring - Environmental magnetism · Particle matter - Road dust - Traffic

\section{Introduction}

Urban air quality is typically surveyed with fixed monitoring stations, which have high temporal accuracy but poor spatial coverage and representativeness due to their limited number. There is an apparent need for enhancing the spatial resolution of air quality studies. By combining magnetic techniques with biomonitoring, the data of atmospheric deposition are obtained easily and efficiently, e.g. for the identification of pollution sources and determining the properties and distribution of particle matter (PM). Practical surrogate indicators of airborne PM (containing iron oxides and heavy metals) include active moss bags (e.g. Salo and Mäkinen 2014; Vuković et al. 2015), epiphytic lichens (e.g. Bajpai 2013; Chaparro et al. 2013), plants (e.g. Castañeda Miranda et al. 2016), tree leaves and needles (e.g. Jordanova et al. 2010; Hansard et al. 2012). Moss bags are easy to place, incorporate various pollutants simultaneously and provide spatially as well as temporally accurate data. Therefore, they are very useful in urban areas lacking native biomonitor species due to high pollution levels or seasonal conditions (Salo et al. 2012, 2016).

Traffic is the major air pollution source in urban areas especially when heavy industry is not present. Traffic emissions include exhaust gases such as carbon monoxide (CO), carbon dioxide $\left(\mathrm{CO}_{2}\right)$, nitrogen oxides $\left(\mathrm{NO}_{\mathrm{x}}\right)$, volatile organic compounds (VOCs) and hydrocarbons (HC), liquids (leakages), and PM from the abrasion of car parts, such as brakes and tires, and road pavement (Kupiainen 2007; HEI 2010). The amount of road dust is impacted by traffic intensity, vehicle velocity, road type, neighbouring 
environment and meteorological conditions (Duong and Lee 2011). After snow melt in spring, many countries in the northern hemisphere experience a short but intensive road dust period, which typically lasts for $4-8$ weeks. This road dust period is due to road sanding and salting (mainly sodium chloride) as well as the use of studded tires in winter conditions. Dust particles are resuspended through wind, traffic-induced turbulence and spring clean of the streets.

Anthropogenic PM is typically composed of iron oxides and heavy metals such as $\mathrm{Cd}, \mathrm{Fe}, \mathrm{Ni}, \mathrm{Pb}$ and $\mathrm{Zn}$. Some metals such as $\mathrm{Cd}$ are toxic even at very low concentrations (Järup 2006), but heavy metal levels are rarely investigated with monitoring stations. Road dust is a substantial source of $\mathrm{PM}_{10}(\leq 10 \mu \mathrm{m})$ and especially $\mathrm{PM}_{2.5}(\leq 2.5 \mu \mathrm{m})$ in the air (Vallius 2005; Shah and Balkhair 2011). $\mathrm{PM}_{2.5}$ is more harmful than coarser particles because they contain more heavy metals ( $\mathrm{Li}$ et al. 2013), and they can be inhaled deeply in the lungs (e.g. Pope and Dockery 2006; Kampa and Castanas 2008). Exposure to air pollution causes asthma and respiratory or cardiovascular symptoms (Schwartz 2004; Schwarze et al. 2006; Kampa and Castanas 2008). The relative impact of air pollution is greater for children than adults because children's lungs and immune system are not developed to full functionality and children usually spend more time outdoors exposed to air pollutants (Schwartz 2004; Gasana et al. 2012).

The aim of this paper was to investigate the seasonal and spatial variation of traffic-induced PM in order to evaluate the pollutant distribution and accordingly estimate the representativeness of the single air quality monitoring station in the city centre of Turku, southwest (SW) Finland. Study emphasised heavily trafficked sites and places where children typically spend their day, i.e. kindergarten, school and park areas. Magnetic and elemental data were collected by exposing Sphagnum papillosum moss bags separately for road dust period, which is experienced in spring season, and summer season in 2013 .

\section{Materials and methods}

\section{Study area and sampling}

The city of Turku is located on the coast of SW Finland (Fig. 1). It has an area of $306.4 \mathrm{~km}^{2}$ and a population around 180,000 . The air quality of Turku region is significantly impacted by traffic-derived $\mathrm{NO}_{\mathrm{x}}$ and $\mathrm{PM}$, whereas the industrial or energy production emissions have mainly low effect (Ilmanlaadun asiantuntijapalvelut 2010). The single air quality monitoring station measures only $\mathrm{PM}_{10}$ values and operates in the city centre. In $2013, \mathrm{PM}_{10}$ values were $19.0 \mu \mathrm{g} \mathrm{m}^{-3}$ for road dust period and $11.6 \mu \mathrm{g} \mathrm{m}^{-3}$ for summer season (Ilmanlaatuportaali 2015). The majority of 19 sites were located in the city centre (Fig. 1). One of the sites (site 6) was situated at the air quality monitoring station, and the rest of the sites were located near major roads, and kindergarten, school and park areas. Traffic sites were located within $1-5 \mathrm{~m}$ from the road sides. Six city sites $(2-3,4-5,10-11)$ formed paired samples with one of the sites in a kindergarten/school courtyard and the other in an adjacent traffic area. The rural background (BKGD) sites were located in Piikkiö (BKGD 1), about $15 \mathrm{~km}$ in the southeast, and in Parainen (BKGD 2), about $35 \mathrm{~km}$ in the south from Turku. Site 1 was lost in road dust period, and site 5 was lost in summer season.

The sampling was done with standardised moss bag method (SFS 5794, Finnish Standards Association 1994). The green parts of moss Sphagnum papillosum were collected from a natural area and cleaned from litter and other vegetation parts in the laboratory. Moss was acid-washed in $0.5 \mathrm{M} \mathrm{HCl}$ and rinsed three times (à $20 \mathrm{~min}$ ) with deionised $\mathrm{H}_{2} \mathrm{O}$ for evening out the element levels and neutralising the material. One part of the acid-washed moss was stored in the laboratory as control moss, which was not exposed to air pollution. The initial magnetic and elemental concentrations were determined from the control moss, and the averages were subtracted from the exposed moss bags. Therefore, the final moss bag data reflect the accumulation of air pollutants during the study periods.

About $30 \mathrm{~g}$ (wet wg.) of moss was placed in a nylon net with $0.64 \mathrm{~cm}^{2}$ mesh and closed with a cotton thread. At each site, three spherical moss bags were tied in the outer branches of the trees at a height of 2.5-3 m. Sampling was done as two sets in 2013: the first set was placed from April to June (road dust period in spring), and the second set from June to August (summer season). The collection times were 61-62 and 60 days, respectively. For each site, a composite sample was formed in the laboratory. The samples were dried to constant weight in $T<40{ }^{\circ} \mathrm{C}$ and ground to fine powder with Retsch PM100 planetary ball mill (500 rpm, $30 \mathrm{~s}$ ) equipped with a zirconium oxide $\left(\mathrm{ZrO}_{2}\right)$ grinding jar and balls.

\section{Magnetic methods}

Mass-specific susceptibility $\left(\chi \times 10^{-8} \mathrm{~m}^{3} \mathrm{~kg}^{-1}\right)$ is a concentration-dependent parameter, which represents the concentration of magnetic minerals in a sample. Massspecific susceptibility was measured using Bartington MS2B dual-frequency $(0.47$ and $4.7 \mathrm{kHz})$ sensor in the Department of Geography and Geology, University of Turku. Six separate subsamples of two control moss and two separate subsamples of each site were prepared in standard $10 \mathrm{~cm}^{3}$ plastic containers and were measured five times in the low frequency. Thus, the final mass-specific susceptibility of each moss bag site is the average value of two subsamples (10 measurements in total) corrected with 


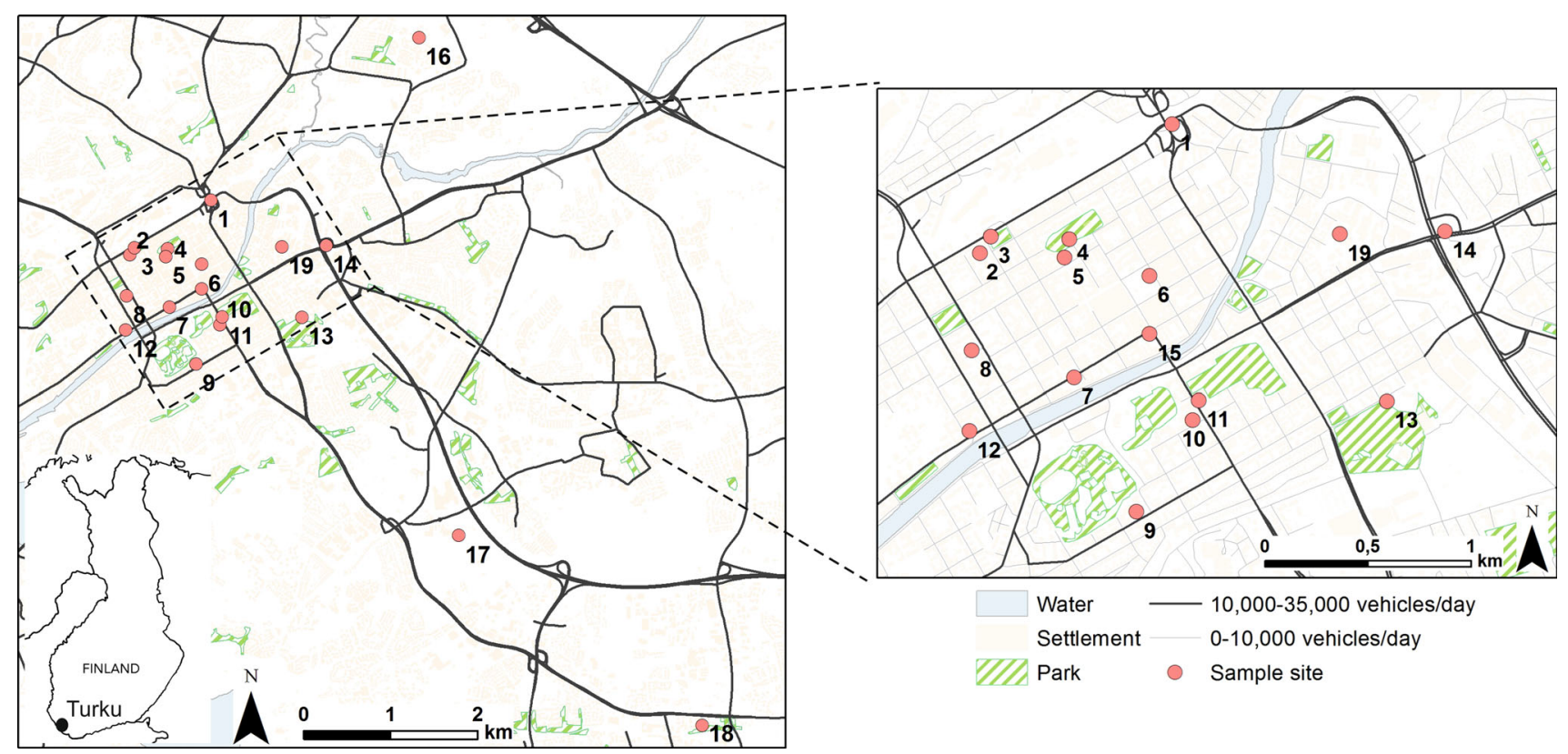

Fig. 1 Map showing the location of sample sites in Turku, SW Finland (rural background sites are located outside the map view). The sites were located mainly in the city centre ( National Land Survey of Finland 2013)

the average value of corresponding control moss $(30$ measurements in total) (Table 1).

Hysteresis loops and temperature dependencies were investigated in order to identify magnetic minerals and their grain sizes in the samples. Determinations were done using Quantum Design SQUID magnetometer in the Department of Physics and Astronomy, University of Turku. Hysteresis loops were determined at temperatures of 10 and $300 \mathrm{~K}$ in a magnetic field up to $1 \mathrm{~T}(\mathrm{~T})$, whereas temperature dependencies were measured from 300 to $10 \mathrm{~K}$ in 10 millitesla $(\mathrm{mT})$. Saturation magnetisation $\left(\mathrm{M}_{\mathrm{S}}\right)$, saturation remanence $\left(\mathrm{M}_{\mathrm{RS}}\right)$, coercive force $\left(\mathrm{H}_{\mathrm{C}}\right)$ and coercivity of remanence $\left(\mathrm{H}_{\mathrm{CR}}\right)$ were obtained after the subtraction of the linear paramagnetic signal from the sample holder and control moss $\mathrm{\kappa}$ by fitting function

$M(B)=M_{R S} \times \operatorname{ArcTan}\left(\left(B \pm H_{c}\right) / B_{s}\right)$

to upward hysteresis loop (with - sign). Here $M(B)$ is the magnetisation as a function of the magnetic field $B$ and $B_{S}$ is a scaling constant. $\mathrm{M}_{\mathrm{S}}$ was determined as the magnetisation value at zero field $\mathrm{M}(0)$. $\mathrm{H}_{\mathrm{CR}}$ was determined by solving numerically the field where the difference of the upward and downward branches was equal to 0.5 .

\section{Chemical analysis}

Elements $\mathrm{Al}, \mathrm{As}, \mathrm{Ca}, \mathrm{Cd}, \mathrm{Cr}, \mathrm{Cu}, \mathrm{Fe}, \mathrm{Hg}, \mathrm{Na}, \mathrm{Ni}, \mathrm{Pb}, \mathrm{Ti}, \mathrm{V}$ and $\mathrm{Zn}$ were analysed in the accredited laboratory, Acme Labs, Canada. The analysis method was VG101. Ground moss samples $(1 \mathrm{~g})$ were dissolved in aqua regia and were analysed by inductively coupled plasma mass spectrometry
(ICP-MS). Three separate subsamples for two control moss were analysed and the average element concentrations (Table 1) were subtracted from the final moss bag data. Two procedural blanks, two reference materials (STD CDV-1 and STD V16) and two separate sample duplicates were analysed at the same time with acceptable results. The detection limits are given in Table 1.

\section{Statistical methods}

Statistical analyses were done with IBM SPSS Statistics version 20. Most of the variables did not follow the normal distribution (Shapiro-Wilk significance $($ sig.) $\leq 0.05$ ). Hence, statistical differences were tested by nonparametric Wilcoxon signed-ranks test with the null hypothesis $\left(\mathrm{H}_{0}\right)$ that the median difference between paired observations is zero. Correlations between the variables were calculated with the Spearman's rank order correlation coefficient $(\rho)$ and the associated level of significance, which is robust to outliers and more appropriate for non-normally distributed data. Nonparametric Kruskal-Wallis test was used to test whether the mean ranks of two groups are the same.

\section{Results and discussion}

\section{Magnetic characteristics of moss bags}

Mass-specific susceptibilities $\left(\chi \times 10^{-8} \mathrm{~m}^{3} \mathrm{~kg}^{-1}\right)$ are the highest at sites next to most trafficked areas (i.e. 10,000-35,000 vehicles per day) and the lowest at 
courtyards or parks. These findings are similar to observations in other studies (e.g. Maher et al. 2008; Vuković et al. 2015). In road dust period, the magnetic enhancement of moss bags is the greatest at sites 3 and 9, which have significant estimated nearby traffic volumes of 40,000 and 34,100 vehicles per day, respectively (Turun kaupunki 2013). The same sites and site 1 , with 13,000 vehicles per day, stand out in summer season. As for paired samples (see Sect. "Study area and sampling"), susceptibilities are slightly higher in traffic than in courtyard sites, except for pair 10-11 $\left(3.2 \times 10^{-8}\right.$ and $\left.2.4 \times 10^{-8} \mathrm{~m}^{3} \mathrm{~kg}^{-1}\right)$ which show a stronger value in the courtyard site in summer season. Maximum values (Table 2), which seem to be similar for both sampling times, are not fully representative due to the loss of site 1 in road dust period near one of the busiest intersections in Turku. For comparison, the moss bags from this site gave $25.6 \times 10^{-8} \mathrm{~m}^{3} \mathrm{~kg}^{-1}$ in road dust period in 2010 (Salo et al. 2012). Rural background values in road dust period and summer season are $0.8 \times 10^{-8}$ and $0.5 \times 10^{-8} \mathrm{~m}^{3} \mathrm{~kg}^{-1}$ in BKGD 1, and $0.3 \times 10^{-8} \mathrm{~m}^{3} \mathrm{~kg}^{-1}$ in BKGD 2, respectively. Urban and industrial references show values similar to park and courtyard sites in the centre.

In this study, susceptibilities of about $>8 \times 10^{-8}$ in road dust period and $>3 \times 10^{-8} \mathrm{~m}^{3} \mathrm{~kg}^{-1}$ in summer season are regarded as typical values indicating traffic impact. Based on average susceptibility values, the magnetic enhancement is approximately three times higher in road dust period than in summer season. A similar ratio was found in road dust period in 2010 between the average susceptibilities of traffic and park sites in Turku (10.1 $( \pm 6.9) \times 10^{-8}$ and $3.1( \pm 1.2) \times 10^{-8} \mathrm{~m}^{3} \mathrm{~kg}^{-1}$, respectively) (Salo et al. 2012). Moreover, Wilcoxon signedranks test shows statistically significantly higher median susceptibilities in road dust period than in summer season $($ sig. $=0.000)$. Road dust period greatly enhances magnetic susceptibilities in spring while normal traffic conditions are the main contributing factor in summer. Seasonal differences in the dust levels have been found in other studies as well (e.g. Kuhns et al. 2003; Gertler et al. 2006).

Rapid saturation of narrow hysteresis loops at $0.2-0.3 \mathrm{~T}$ (Fig. 2a, b) is indicative for low-coercivity ferrimagnetic minerals, such as magnetite. Before the subtraction of the linear paramagnetic signal, hysteresis loops indicate iron to be present also either in paramagnetic or superparamagnetic (SP) form. Moreover, $\mathrm{M}_{\mathrm{S}}$ and $\mathrm{H}_{\mathrm{C}}$ are stronger in low-temperature than room-temperature hysteresis loops. At $10 \mathrm{~K}$, average $\mathrm{H}_{\mathrm{C}}$ is $11.0( \pm 3.1) \mathrm{mT}$ and $\mathrm{H}_{\mathrm{CR}} 124.6( \pm 10.8) \mathrm{mT}$ for road dust period and $10.7( \pm 4.5) \mathrm{mT}$ and $111.4( \pm 9.6) \mathrm{mT}$, respectively, for summer season. At $300 \mathrm{~K}$, average values for $\mathrm{H}_{\mathrm{C}}$ are $5.8( \pm 1.1) \mathrm{mT}$ and $5.3( \pm 0.8) \mathrm{mT}$ and for $\mathrm{H}_{\mathrm{CR}} 64.8$ $( \pm 8.9) \mathrm{mT}$ and $72.4( \pm 9.3) \mathrm{mT}$, respectively. Low to intermediate $\mathrm{H}_{\mathrm{C}}$ values found in this study are typical for magnetite as well as greigite (Sagnotti 2007). 

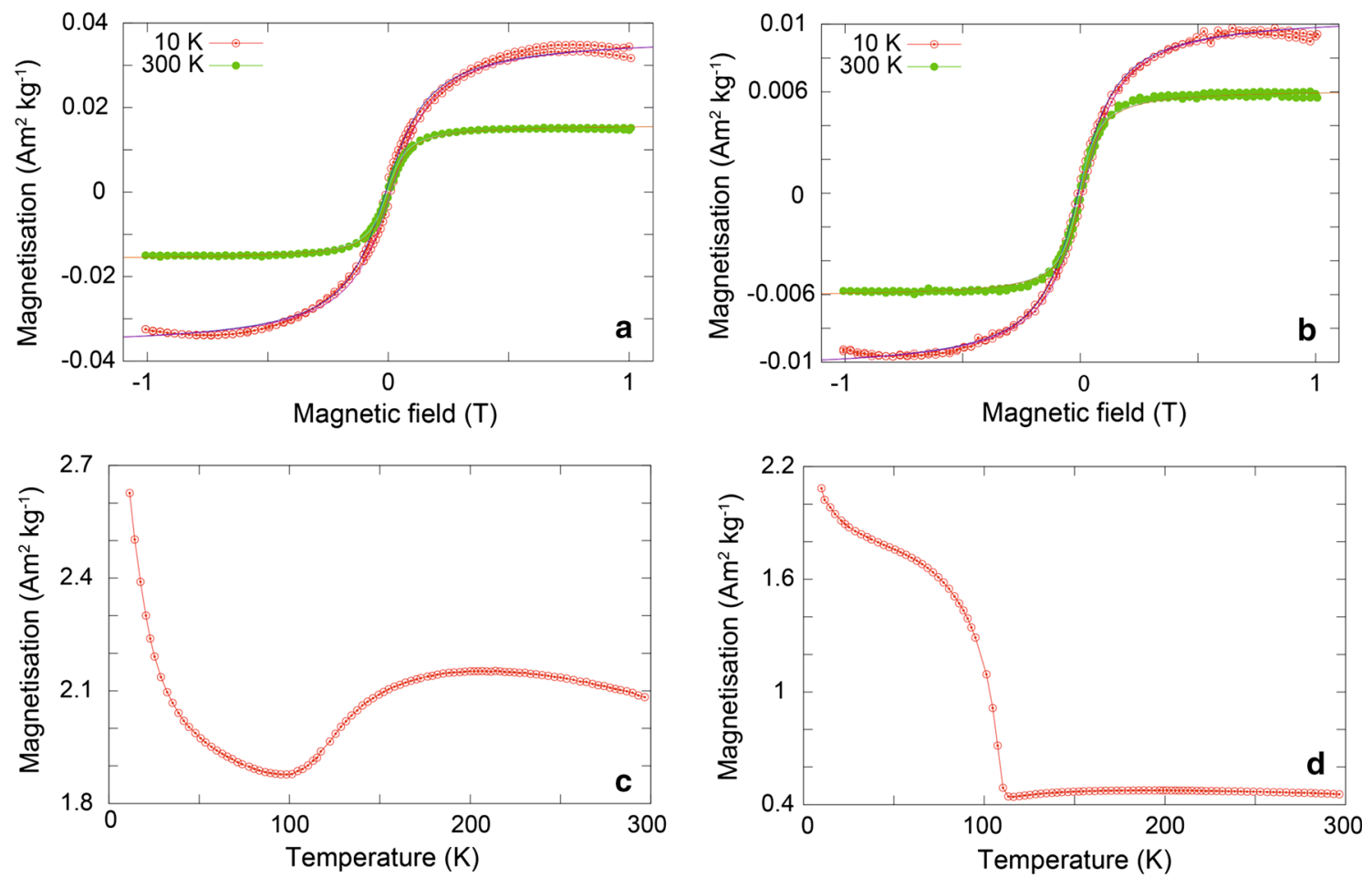

Fig. 2 Hysteresis loops measured at 10 and $300 \mathrm{~K}$ for site 9 in road dust period (a) and summer season (b), and temperature-dependent magnetisation measured at magnetic field of $10 \mathrm{mT}$ for site 3 in road dust period (c) and for site 11 in summer season (d)

Temperature-dependent magnetisation shows Verwey transition $\left(\mathrm{T}_{\mathrm{V}}\right)$ near $120 \mathrm{~K}$ (Özdemir et al. 2002), which points to magnetite as the main magnetic mineral in both sampling times (Fig. 2c, d). However, most samples have a smeared transition and a gradual rise of magnetisation after $T_{\mathrm{V}}$ (Fig. 2c). This indicates that magnetite is partly SP or partially oxidised, i.e. non-stoichiometric (Smirnov 2006; Mitchell and Maher 2009). The previous study (Salo et al. 2012) suggested that urban dust of Turku contains SP particles. In the Day plot (Fig. 3a, b), samples site in the pseudo-single-domain (PSD) region is close to the theoretical mixing line for superparamagnetic (SP)-single-domain (SD) grains. Samples are more dispersed in summer than in road dust period indicating a wider range of magnetite grain diameters (Fig. 3a). In road dust period, magnetite PM is quite similar regardless of site location, while in summer season indications for magnetite PM to be closer to SP-SD mixing line at courtyard/park sites than at traffic sites are shown (Fig. 3b). According to Dearing (1999), PSD and SD particles tend to form in fossil fuel combustion while SP particles form for example in pedogenic processes.

\section{Element concentrations of moss bags}

Based on mean concentrations, the element order is almost the same between sampling times: $\mathrm{Ca}>\mathrm{Fe}>\mathrm{Al}>$
$\mathrm{Na}>\mathrm{Ti}>\mathrm{Zn}>\mathrm{Cu}>\mathrm{V}>\mathrm{Cr}>\mathrm{Pb}>\mathrm{Ni}>\mathrm{As}>\mathrm{Cd}>$ $\mathrm{Hg}$ in road dust period and $\mathrm{Ca}>\mathrm{Fe}>\mathrm{Al}>\mathrm{Na}>\mathrm{Zn}>$ $\mathrm{Ti}>\mathrm{Cu}>\mathrm{Cr}>\mathrm{Ni}=\mathrm{Pb}>\mathrm{V}>\mathrm{As}>\mathrm{Cd}>\mathrm{Hg}$ in summer season (Table 2). Sites 3, 9, 15 and sites 1, 2, 10, respectively, are distinct by means of higher element concentrations. Sites 2 and 10 are located at kindergarten courtyards but close to heavily trafficked roads and the others are sited at traffic areas. Sites next to heavy traffic show typically greater element enhancement (e.g. Maher et al. 2008; Salo et al. 2012). Wilcoxon signed-ranks test shows that the difference in median values was statistically significant (sig. $<0.05$ ) between paired variables, excluding As, Hg and Zn. Furthermore, ranking the differences indicates higher element values in road dust period, except for $\mathrm{Hg}$ which was higher in summer. The rural background sites are among the lowest element values (Table 2).

For paired samples 2-3, 4-5 and 10-11 (see Sect. "Study area and sampling"), courtyard/park sites show higher concentrations for several elements in both sampling times compared to traffic sites: especially $\mathrm{Cd}, \mathrm{Hg}, \mathrm{Pb}$ and $\mathrm{Zn}$ stand out in all pairs while, for example, As, Ni, Ti and $\mathrm{V}$ are distinctive in most pairs (Table 3).

Average monthly concentrations ( $\mathrm{mg} \mathrm{kg}^{-1}$ per month) of this and previous study (Salo and Mäkinen 2014) show the most elemental levels to be significantly lower (e.g. $\mathrm{Cu}$ about 120 and 130 times lower in road dust period and summer season, respectively) in the city of Turku than in the 


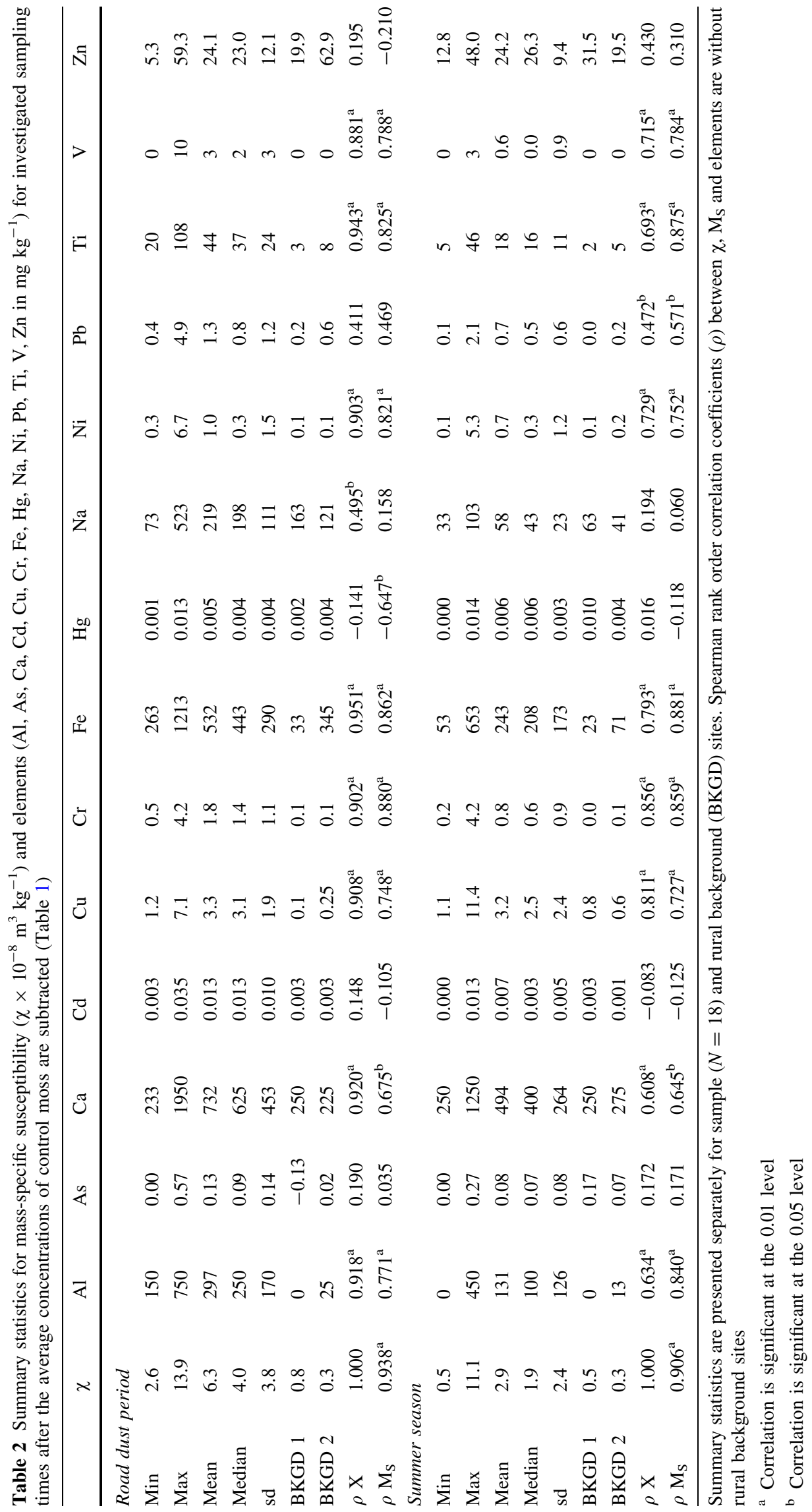


Fig. 3 Day plot of ratios $M_{\mathrm{RS}} /$ $M_{\mathrm{S}}$ and $H_{\mathrm{CR}} / H_{\mathrm{C}}$ of the moss bag samples in road dust period and summer season (a) and different city centre sites in road dust period and summer season (b) measured at $300 \mathrm{~K}$. Singledomain (SD), pseudo-singledomain (PSD) and multidomain (MD) boundaries for grains and mixing lines are shown after Dunlop (2002)
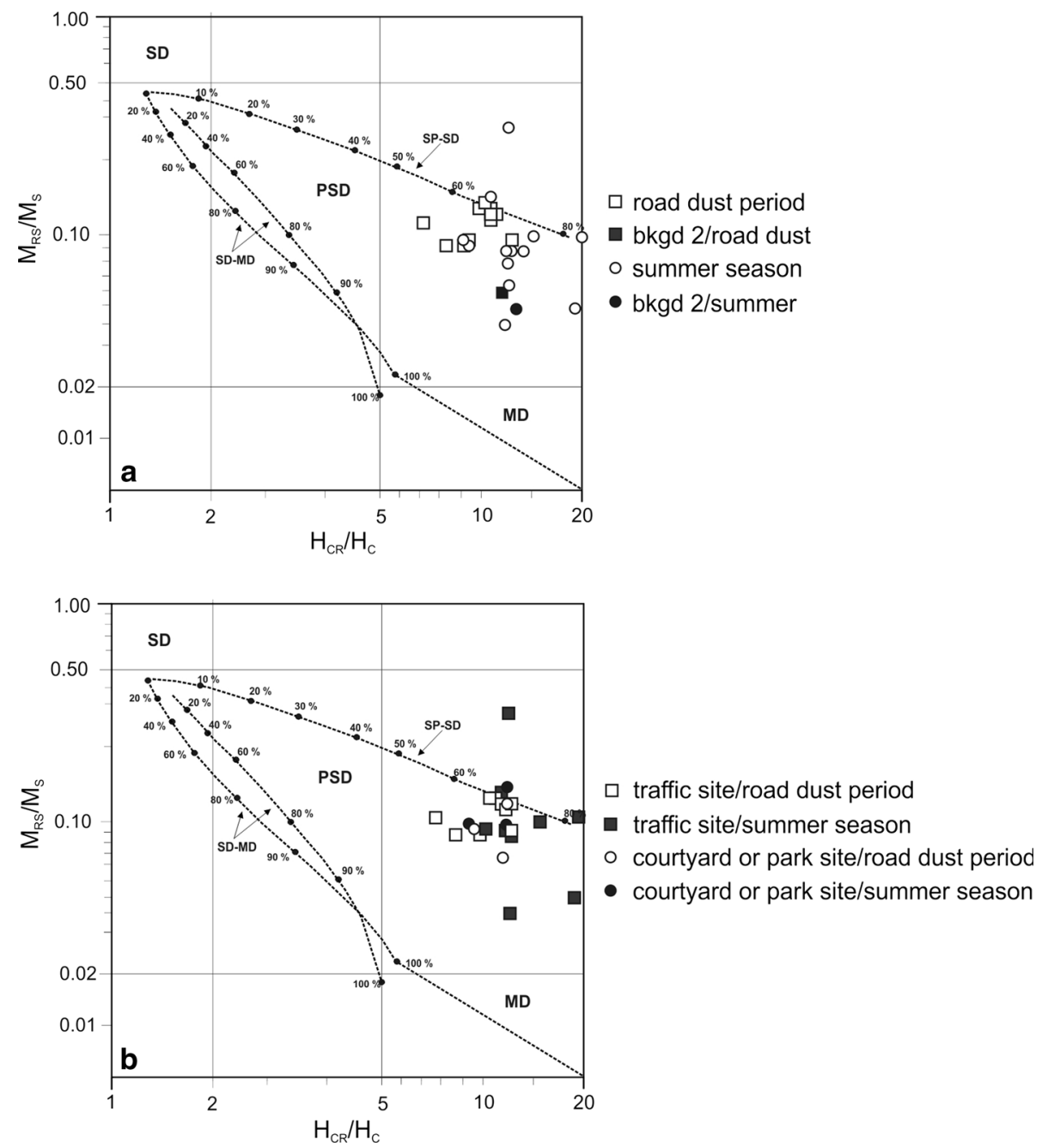

Table 3 Summary of elements having higher concentrations in paired samples for courtyard/park sites than in traffic sites in road dust period and summer season

\begin{tabular}{lll}
\hline $\begin{array}{l}\text { Sample } \\
\text { pair }\end{array}$ & Elements, road dust period & Elements, summer season \\
\hline $2>3$ & $\mathrm{Ca}, \mathbf{C d}, \mathrm{Hg}, \mathbf{P b}, \mathbf{Z n}$ & $\begin{array}{c}\mathrm{As}, \mathrm{Al}, \mathbf{C d}, \mathrm{Fe}, \mathrm{Na}, \mathrm{Ni}, \mathbf{P b}, \\
\mathrm{Ti}, \mathrm{V}, \mathbf{Z n}\end{array}$ \\
$4>5$ & $\mathrm{Al}, \mathrm{Ca}, \mathbf{C d}, \mathrm{Cu}, \mathrm{Cr}, \mathrm{Fe}, \mathrm{Hg}$, & - \\
& $\mathrm{Na}, \mathrm{Ni}, \mathbf{P b}, \mathrm{Ti}, \mathrm{V}, \mathbf{Z n}$ & \\
$10>11$ & $\mathrm{As}, \mathbf{C d}, \mathrm{Hg}, \mathbf{P b}, \mathbf{Z n}$ & $\mathrm{Al}, \mathrm{Ca}, \mathbf{C d}, \mathrm{Cu}, \mathrm{Cr}, \mathrm{Fe}, \mathrm{Hg}$, \\
& & $\mathrm{Na}, \mathrm{Ni}, \mathbf{P b}, \mathrm{Ti}, \mathrm{V}, \mathbf{Z n}$
\end{tabular}

The joint elements showing higher concentrations during both sampling times are bolded. Site 5 was lost in summer season

industrial town of Harjavalta. However, the average concentrations of $\mathrm{Al}$ and $\mathrm{Ti}$ are higher in Turku where traffic is the main pollution source. This might reflect the polluting effect of increased traffic and/or road dust period (e.g. Peltier et al. 2011). Previous moss bag studies from Harjavalta indicate that $\mathrm{Ti}$ is the only investigated element that shows notably increasing concentrations (close to the main highways) between 1996/1997 and 2001/2002 despite the reductions in the industrial emissions (Jussila 1997, 2003).

\section{Correlations of magnetic properties and elements}

The majority of Spearman's rank order correlations between the elements, $\chi$ and $\mathrm{M}_{\mathrm{S}}$ are statistically significant (Table 2; Fig. 4). Such associations are typical for enviromagnetic studies and highlight magnetic parameters as good proxy for heavy metal pollution (e.g. Yang et al. 2010; Salo and Mäkinen 2014). In road dust period, elements correlate overall stronger with $\chi$ than $M_{\mathrm{S}}$ while situation is vice versa in summer season. Correlations are the weakest with $\mathrm{As}, \mathrm{Cd}, \mathrm{Hg}$ and $\mathrm{Zn}$ in both sampling times as well as $\mathrm{Na}$ in summer season. First three elements are released to air mainly from industrial sources (Alaviippola et al. 2007), $\mathrm{Zn}$ also from traffic activities ( $\mathrm{Ng}$ et al. 2003) while $\mathrm{Na}$ is present in road salt, which is not used in summer (ELY-keskus 2013). Thus, other elements, such as 
$\mathrm{Al}, \mathrm{Fe}$ and $\mathrm{Ni}$, are present in higher volumes in trafficinduced pollution in Turku and are more effectively merged with magnetic PM.

\section{Spatial representativeness of the air quality monitoring station}

Data gathered by air quality monitoring stations are extended to apply spatially large areas. Along the same principle, the results of moss bags from site 6 at the only monitoring station in Turku could represent the whole urban centre. Here the susceptibility value is $9.4 \times 10^{-8}$ in road dust period and $1.9 \times 10^{-8} \mathrm{~m}^{3} \mathrm{~kg}^{-1}$ in summer season. The rest of the sites (excluding rural backgrounds) have the average values of 6.1 (range 2.6-13.9) $\times 10^{-8}$ and 2.9 (range $0.5-11.1$ ) $\times 10^{-8} \mathrm{~m}^{3} \mathrm{~kg}^{-1}$, respectively. Element values show same order; for example, corresponding values for $\mathrm{Al}$ in road dust period are $350 \mathrm{mg} \mathrm{kg}^{-1}$ and 294 (range $150-750$ ) $\mathrm{mg} \mathrm{kg}^{-1}$ while in summer season $50 \mathrm{mg} \mathrm{kg}^{-1}$ and 135 (range 0-450) $\mathrm{mg} \mathrm{kg}^{-1}$. It seems that in general the accumulation of elements in site 6 is overestimated in road dust period and underestimated in summer season, for example site 10 . However, statistically the mean ranks of site 6 and the rest of the sites are not significantly different (sig. $>0.05$ ). Nevertheless, based on the seasonal and spatial differences in the magnetic and elemental data, it is concluded that the current location of air monitoring station in Turku is not ideal and should be further assessed.

The spatial representativeness of monitoring stations is currently under the consideration of EU. Magnetic biomonitoring could be a powerful tool in assessing the impact area of a station. It could also provide spatially and vertically detailed data of pollution levels and distribution required for air quality modelling purposes. More research

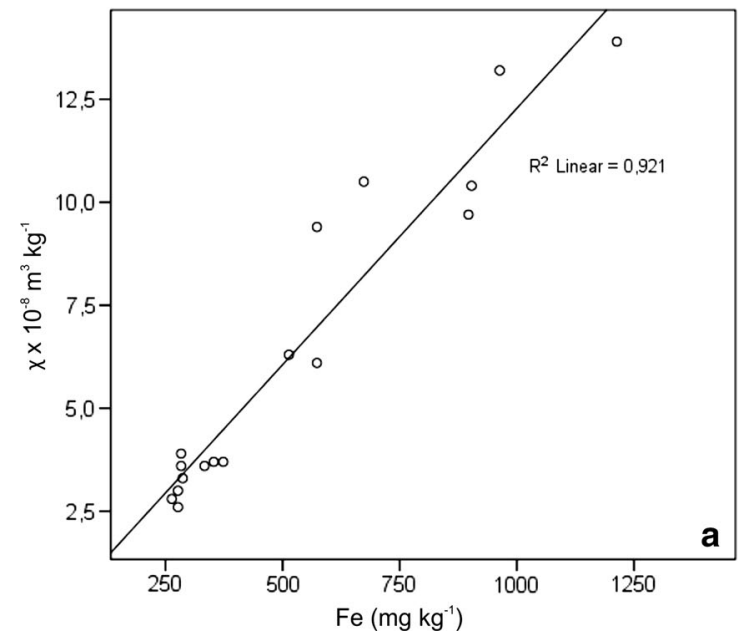

is needed in order to establish the relationship between monitoring station and biomonitoring data sets.

\section{Results in relation to sampling times and human health}

In the spring, traffic sites are highly loaded both magnetically and elementally by road dust. Road dust period is a short but intensive period, which can cause difficulties to even those not suffering from respiratory problems. Thus, summer values represent more of a normal situation where vegetation might have an impact. Vegetation is usually considered to be effective in mitigating air pollution dispersal and trapping PM: for example, Vos et al. (2013) stated that leaves absorb gaseous pollutants through stomata while particles are deposited on the leaves and branches; and Maher et al. (2008) detected higher saturation isothermal remanence (SIRM), Fe and $\mathrm{Pb}$ values on roadside than road-proximal tree leaves. On the contrary, vegetation can have locally negative impacts on air quality. For instance, trees and leaves can obstruct wind flow, hold pollutants within the canopy and prevent fresh air ventilation (Roy et al. 2012; Salmond et al. 2013). However, Setälä et al. (2013) reported that trees ability to remove air pollutants is minor in northern climates. In order to investigate the air pollution under normal conditions, i.e. outside road dust period and its masking effect, comparison should be made between summer and autumn seasons.

According to Dekkers (1997), upper threshold for PSD grains is about $10 \mu \mathrm{m}$ while SD grains are between 0.03 and $0.50 \mu \mathrm{m}$ and SP grains below $0.03 \mu \mathrm{m}$. Since anthropogenic PM entrapped by moss bags in Turku is composed of PSD magnetite towards SP-SD grain sizes (Fig. 3a, b), it is most likely closer to $\mathrm{PM}_{<2.5}$ than $\mathrm{PM}_{10}$. Moreover, Tretiach et al. (2011) stated that moss bags capture $\mathrm{PM}_{<2.5}$

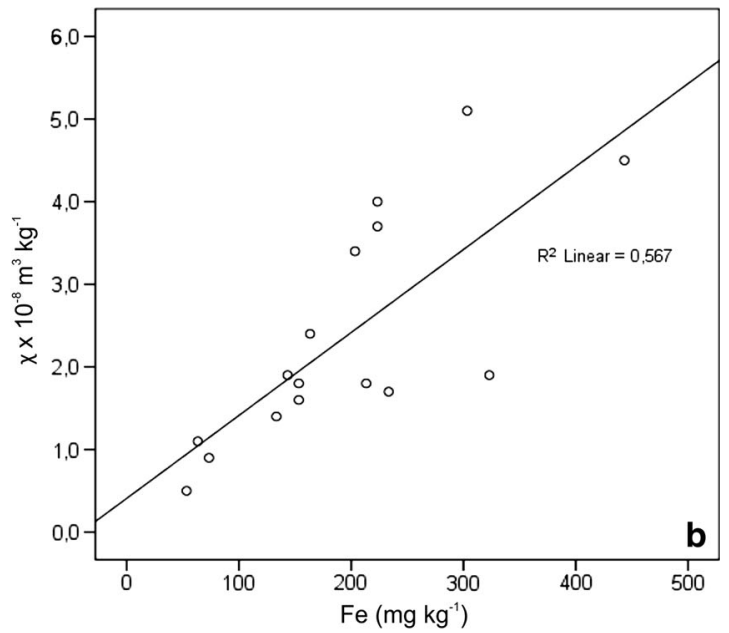

Fig. 4 Representative correlation plot for magnetic susceptibility and Fe in road dust period (a) and summer season (b) without outliers, i.e. sites 1 and 10 
predominantly $(79 \%)$ over coarser fraction of $\mathrm{PM}_{2.5-10}$. These small particles are harmful to human health because they access respiratory systems and especially deeper parts of the lungs more easily than larger particles. Previous studies have reported urban PM in sizes of about $0.2-5 \mu \mathrm{m}$ (Chaparro et al. 2013), about 0.1-1 $\mu \mathrm{m}$ (Mitchell and Maher 2009) and about 0.1-5 $\mu \mathrm{m}$ (Sagnotti et al. 2009).

In the city centre, smaller PM as well as higher element levels are found in courtyard/park sites than in traffic sites especially in summer season (Fig. 3b). Courtyard sites are closed and sheltered, so air is not mixed and pollutant levels are not diluted by wind as effectively as in street areas. Children typically spend much time on kindergarten and school courtyards and thus can be exposed to the most harmful PM and elements. Traffic emissions also occur near ground level along streets with pedestrians and cyclists; for example, Maher et al. (2008) reported peak values in traffic-emitted particles at small child height of about $0.3 \mathrm{~m}$ and adult head height of $1.5-2 \mathrm{~m}$ above the ground level. Since moss bags were located above $(\sim 2.5 \mathrm{~m})$ the average height of children, and adults as well, the data might underestimate the conditions for respiratory exposure. The same conditions apply for the air quality monitoring stations with collectors at $3 \mathrm{~m}$. Furthermore, urban air quality data and derived dispersion models are not spatially representative or informative, especially in the case of sheltered areas such as courtyards. By enhancing the representativeness of air pollution data, more accurate information can be provided for environmental management purposes and health studies.

\section{Conclusion}

Based on the active magnetic biomonitoring, the single air monitoring station in the city centre of Turku overestimates road dust period and underestimates traffic impact in summer season. The magnetic properties indicate PM in Turku to be composed of fine-grained PSD magnetite towards SPSD sizes. The presence of iron in SP form is strengthened by original hysteresis loops as well as by temperature-dependent magnetisation. In general, the enhancement is greater in road dust period and near traffic sites than in summer season and in courtyard/park sites. Three paired samples show higher element loads and finer grain sizes in summer at kindergarten courtyard/park sites compared to traffic sites, which is worrying considering children. Therefore, further studies are important for revealing the spatial and vertical distribution of pollutants and their characteristics in urban areas, especially in courtyard sites. Active magnetic biomonitoring can provide elaborate pollution and PM size data necessary for the assessment of the spatial representativeness of air quality monitoring stations, for enhancement of air quality models, as well as for environmental management purposes and health investigations.

Acknowledgments Study was funded by TOP Foundation. PP acknowledges the Jenny and Antti Wihuri Foundation for financial support. The contribution of anonymous referees for improving this paper is highly appreciated. Authors wish to thank Miika Meretoja from Turku Environmental Protection Office for valuable information and technical support and Professor Timo Saarinen for constructive comments.

\section{References}

Alaviippola B, Pietarila H, Hakola H, Hellén H, Salmi T (2007) Ilmanlaadun alustava arviointi Suomessa. Arseeni, kadmium, nikkeli, elohopea ja polysykliset aromaattiset hiilivedyt (= PAHyhdisteet). Ilmatieteen laitos, Ilmanlaadun asiantuntijapalvelut. 120 p. (in Finnish)

Bajpai R, Shukla V, Upreti DK (2013) Impact assessment of anthropogenic activities on air quality, using lichen Remototrachyna awasthii as biomonitor. Int J Environ Sci Technol 10(6):1287-1294. doi:10.1007/s13762-012-0156-1

Castañeda Miranda AG, Chaparro MAE, Chaparro MAE, Böhnel HN (2016) Magnetic properties of Tillandsia recurvata $\mathrm{L}$. and its use for biomonitoring a Mexican metropolitan area. Ecol Indic 60:125-136. doi:10.1016/j.ecolind.2015.06.025

Chaparro MAE, Lavornia JM, Chaparro AE, Sinito AM (2013) Biomonitors of urban air pollution: magnetic studies and SEM observations of corticolous foliose and microfoliose lichens and their suitability for magnetic monitoring. Environ Pollut 172:61-69. doi:10.1016/j.envpol.2012.08.006

Dearing J (1999) Environmental magnetic susceptibility. Using the Bartington MS2 system. Bartington Instruments, Oxford

Dekkers MJ (1997) Environmental magnetism: an introduction. Geol Mijnbouw 76(1):163-182. doi:10.1023/A:1003122305503

Dunlop DJ (2002) Theory and application of the Day plot $\left(\mathrm{M}_{\mathrm{rs}} / \mathrm{M}_{\mathrm{s}}\right.$ versus $\left.\mathrm{H}_{\mathrm{cr}} / \mathrm{H}_{\mathrm{c}}\right)$ 1. Theoretical curves and tests using titanomagnetite data. J Geophys Res. doi:10.1029/2001JB000486

Duong TTT, Lee B-K (2011) Determining contamination level of heavy metals in road dust from busy traffic areas with different characteristics. J Environ Manage 92(3):554-562. doi:10.1016/j. jenvman.2010.09.010

ELY-keskus [Elinkeino-, liikenne- ja ympäristökeskus] (2013) Talvihoito. <https://www.ely-keskus.fi/web/ely/talvihoito?p_p_id= 122_INSTANCE_aluevalinta\&p_p_lifecycle $=0 \& p \_p \_s t a t e=$ normal\&p_p_mode $=$ view\&p_r_p_564233524_resetCur $=$ true $\&$ p_r_p_564233524_categoryId=14252\#.VZOGUGNqOtH $>$ Accessed Jul 1 2015. (in Finnish)

Finnish Standards Association (1994) SFS 5794. Air protection. Bioindication. Moss bag method

Gasana J, Dillikar D, Mendy A, Forno E, Vieira ER (2012) Motor vehicle air pollution and asthma in children: a meta-analysis. Environ Res 117:36-45. doi:10.1016/j.envres.2012.05.001

Gertler A, Kuhns H, Abu-Allaban M, Damm C, Gillies J, Etyemezian V, Clayton R, Profitt D (2006) A case study of the impact of winter road sand/salt and street sweeping on road dust reentrainment. Atmos Environ 40(31):5976-5985. doi:10.1016/j. atmosenv.2005.12.047

Hansard R, Maher BA, Kinnersley RP (2012) Rapid magnetic biomonitoring and differentiation of atmospheric particulate pollutants at the roadside and around two major industrial sites in the UK. Environ Sci Technol 46(8):4403-4410. doi:10.1021/ es $203275 r$ 
HEI [Health Effects Institute] (2010) Traffic-related air pollution: a critical review of the literature on emissions, exposure, and health effects. Special report 17. Boston, Massachusetts

Ilmanlaadun asiantuntijapalvelut (2010) Turun seudun päästöjen leviämismalliselvitys. Ilmatieteen laitos, Helsinki. (in Finnish)

Ilmanlaatuportaali (2015) Tarkistetut mittaustulokset. <http://www. ilmanlaatu.fi/tarkistetut_tulokset/> Accessed Oct 12 2015. (in Finnish)

Järup L (2006) Hazards of heavy metal contamination. Br Med Bull 68(1):167-182. doi:10.1093/bmb/ldg032

Jordanova D, Petrov P, Hoffmann V, Gocht T, Panaiotu C, Tsacheva T, Jordanova N (2010) Magnetic signature of different vegetation species in polluted environment. Stud Geophys Geod 54(3):417-442. doi:10.1007/s11200-010-0025-7

Jussila I (1997) Porin-Harjavallan ja Pohjois-Satakunnan alueen ilman laadun seuranta bioindikaattorien avulla vuosina 1996-1997. Turun yliopisto, Satakunnan ympäristöntutkimuslaitos. Sykesarja B 12, Pori. 78 p. (in Finnish)

Jussila I (2003) Porin-Harjavallan alueen sammalpallotutkimukset vuosina 2001-2002. Turun yliopisto, Satakunnan ympäristöntutkimuslaitos. Sykesarja B 15, Pori. 112 p. (in Finnish)

Kampa M, Castanas E (2008) Human health effects of air pollution. Environ Pollut 151(2):362-367. doi:10.1016/j.envpol.2007.06. 012

Kuhns H, Etyemezian V, Green M, Hendrickson K, McGown M, Barton K, Pitchford M (2003) Vehicle-based road dust emission measurement-Part II: effect of precipitation, wintertime road sanding, and street sweepers on inferred $\mathrm{PM}_{10}$ emission potentials from paved and unpaved roads. Atmos Environ 37(32):4573-4582. doi:10.1016/S1352-2310(03)00529-6

Kupiainen K (2007) Road dust from pavement wear and traction sanding. Monographs of the Boreal Environment Research, Finnish Environmental Institute, Helsinki

Li H, Qian X, Wang Q (2013) Heavy metals in atmospheric particulate matter: a comprehensive understanding is needed for monitoring and risk mitigation. Environ Sci Technol 47(23):13210-13211. doi:10.1021/es404751a

Maher BA, Moore C, Matzka J (2008) Spatial variation in vehiclederived metal pollution identified by magnetic and elemental analysis of roadside tree leaves. Atmos Environ 42(2):364-373. doi:10.1016/j.atmosenv.2007.09.013

Mitchell R, Maher BA (2009) Evaluation and application of biomagnetic monitoring of traffic-derived particulate pollution. Atmos Environ 43(13):2095-2103. doi:10.1016/j.atmosenv. 2009.01.042

National Land Survey of Finland (2013) Topographic. Database 1(10):000

Ng SL, Chan LS, Lam KC, Chan WK (2003) Heavy metal contents and magnetic properties of playground dust in Hong Kong. Environ Monit Assess 89(3):221-232. doi:10.1023/A: 1026103318778

Özdemir Ö, Dunlop DJ, Moskowitz BM (2002) Changes in remanence, coercivity and domain state at low temperature in magnetite. Earth Planet Sci Lett 194(3-4):343-358. doi:10.1016/ S0012-821X(01)00562-3

Peltier RE, Cromar KR, Ma Y, Fan Z-H, Lippmann M (2011) Spatial and seasonal distribution of aerosol chemical components in New York City: (2) road dust and other tracers of trafficgenerated air pollution. J Expo Sci Environ Epidemiol 21(5):484-494. doi:10.1038/jes.2011.15

Pope CA, Dockery DW (2006) Health effects of fine particulate air pollution: lines that connect. J Air Waste Manage Assoc 56(6):709-742. doi:10.1080/10473289.2006.10464485
Roy S, Byrne J, Pickering C (2012) A systematic quantitative review of urban tree benefits, costs, and assessment methods across cities in different climatic zones. Urban For Urban Green 11(4):351-363. doi:10.1016/j.ufug.2012.06.006

Sagnotti L (2007) Iron sulfides. In: Gubbins D, Herrero-Bervera E (eds) Encyclopedia of geomagnetism and paleomagnetism. Springer, Amsterdam, pp 453-454

Sagnotti L, Taddeucci J, Winkler A, Cavallo A (2009) Compositional, morphological, and hysteresis characterization of magnetic airborne particulate matter in Rome, Italy. Geochem Geophys Geosyst 10(8):Q08Z06. doi:10.1029/2009GC002563

Salmond JA, Williams DE, Laining G, Kingham S, Dirks K, Longley I, Henshaw GS (2013) The influence of vegetation on the horizontal and vertical distribution of pollutants in a street canyon. Sci Total Environ 443:287-298. doi:10.1016/j.scitotenv. 2012.10.101

Salo H, Mäkinen J (2014) Magnetic biomonitoring by moss bags for industry-derived air pollution in SW Finland. Atmos Environ 97:19-27. doi:10.1016/j.atmosenv.2014.08.003

Salo H, Berisha A-K, Mäkinen J (2016) Seasonal comparison of moss bag technique against vertical snow samples for monitoring atmospheric pollution. J Environmen Sci 41:128-137. doi:10. 1016/j.jes.2015.04.021

Salo H, Bućko M, Vaahtovuo E, Limo J, Mäkinen J, Pesonen L (2012) Biomonitoring of air pollution in SW Finland by magnetic and chemical measurements of moss bags and lichens. J Geochem Explor 115:69-81. doi:10.1016/j.gexplo.2012.02.009

Schwartz J (2004) Air pollution and children's health. Pediatrics 113(4):1037-1043

Schwarze PE, Øvrevik J, Låg M, Refsnes M, Nafstad P, Hetland RB, Dybing E (2006) Particulate matter properties and health effects: consistency of epidemiological and toxicological studies. Hum Exp Toxicol 25(10):559-579. doi:10.1177/096032706072520

Setälä H, Viippola V, Rantalainen AL, Pennanen A, Yli-Pelkonen V (2013) Does urban vegetation mitigate air pollution in northern conditions? Environ Pollut 183:104-112. doi:10.1016/j.envpol. 2012.11.010

Shah PS, Balkhair T (2011) Air pollution and birth outcomes: a systematic review. Environ Int 37(2):498-516. doi:10.1016/j. envint.2010.10.009

Smirnov AV (2006) Memory of the magnetic field applied during cooling in the low-temperature phase of magnetite: grain size dependence. J Geophys Res 111:B12. doi:10.1029/ 2006JB004573

Tretiach M, Pittao E, Crisafulli P, Adamo P (2011) Influence of exposure sites on trace element enrichment in moss-bags and characterization of particles deposited on the biomonitor surface. Sci Total Environ 409(4):822-830. doi:10.1016/j.scitotenv.2010. 10.026

Turun kaupunki (2013) Liikennemääräkartta

Vallius M (2005) Characteristics and sources of fine particulate matter in urban air. Publications of the National Public Health Institute, A 6/2005. National Public Health Institute, Department of Environmental Health, Kuopio

Vos PEJ, Maiheu B, Vankerkom J, Janssen S (2013) Improving local air quality in cities: to tree or not to tree? Environ Pollut 183:113-122. doi:10.1016/j.envpol.2012.10.021

Vuković G, Aničić Urošević M, Tomašević M, Samson R, Popović A (2015) Biomagnetic monitoring of urban air pollution using moss bags (Sphagnum girgensohnii). Ecol Indic 52:40-47. doi:10.1016/j.ecolind.2014.11.018

Yang T, Liu Q, Li H, Zeng Q, Chan L (2010) Anthropogenic magnetic particles and heavy metals in the road dust: magnetic identification and its implications. Atmos Environ 44(9):1175-1185. doi:10.1016/j.atmosenv.2009.12.028 